\title{
Effect of Some Medicinal Plants on the Activity of Some Immunological Factors in Saliva and Serum of Type - II Diabetics
}

\author{
Rawdha K. Al-Jammas* \\ Ferial A. Al-Mahdawi** \\ Abbas F. Al-Mukhtar***
}

Received 20, December, 2012

Accepted 3, March, 2014

\begin{abstract}
:
The study involved 45 male and 45 females of diabetic patients type- 11 aged from 40-69years, and with the same numbers of males and females for control, all the patients and controls were without any periodontal diseases and without any systemic disease. Diabetic patients were divided in to three groups according to the degree of periodontitis, and the inflamed gingiva of all groups of diabetic patients were treated with the dried fruits powder (crude) of medicinal plants Quercus robur, Thuja occidenalis, Terminalia chebula, Anethum graveolens, respectively and mixture.

Some immunological and antimicrobial factors (IgA, Lactoferrin , Lysozyme ) , were detected in serum and saliva of diabetic patients and the controls, the results revealed that the level of $\operatorname{IgA}$, Lysozyme in saliva were more than in serum of the control, and this will insure that these factors are considered to be generally protected against bacteria in the oral cavity . Also there was a significant increase at $(p<0.001)$ especially after treatment with the mixture of medicinal plants, so that the mixture of these plants can be considered the best type in the treatment of inflamed gingiva of type -11 diabetic patients.
\end{abstract}

\section{Key words: Medical Plants, Saliva,Type -n Diabetics}

\section{Introduction:}

Medicinal plants have been used as traditional treatments for numerous human diseases for thousands of years and in many parts of the world. In rural areas of the developing countries, they continue to be used as the primary source of medicine [ 1]. About $80 \%$ of the people in developing countries use traditional medicines for their health care [ 2 ]. There have been numerous reports of the use of traditional plants and natural products for the treatment of oral diseases . Many plant - derived medicines used in traditional medicinal systems have been recorded in pharmacopeias as agents used to treat infections and a number of these have been recently investigated for their efficacy against oral microbial pathogens. The general antimicrobial activities of medicinal plants and plant products such as essential oils , have been reviewed previously $[3,4]$. This study involved some medicinal plants (Quercus robur , Thuja occidentalis , Terminalia chebula, Anethum graveolens) , that had tannins , volatile oils, flavonoids , gallic acid , water-soluble immunostimulating polysaccharides and glycoprotiens [5]. These plant act as antibacterial activity against

*College of Educ. For Girls /University of Mosul/Dept.of Biol

**College of Science/ University of Baghdad/Dept.of Biol

***College of Dentist/ University of Baghdad/Dept.of Biol 
human pathogenic Gram positive and Gram negative bacteria [6]. Also had an antifungal activity, that used in the inflammation of the mouth and pharynx $[7,8]$. Diabetes is a group of metabolic diseases characterized by hyperglycemia resulting from defects in insulin secretion, insulin action, or both. The chronic hyperglycemia of diabetes is associated with long-term damage, dysfunction, and failure of different organs, especially the eyes, kidneys, nerves , heart, and blood vessels . Several pathogenic processes are involved in the development of diabetes[10] .

Some immunological factors involved in this study (IgA , Lysozyme , lactoferrin , lysyloxidase), $\operatorname{Ig} \mathrm{A}$ is the most abundant antibody produced by the body, and is present both in the blood stream as well as in a secreted form on the surface of mucus membranes. The most important role of $\operatorname{IgA}$ is to protect against infection from the numerous bacteria that are present on the mucus membranes. IgA acts to coat the surface of bacteria, which are then destroyed by a variety of immune mechanisms[11.

Salivary lysozyme (SLZ) is a proteolytic enzyme expressed by neutrophil leukocytes in response to infection [ 12], and is capable of cleaving the glycosidic linkage on the bacterial cell wall resulting in an anti-infective action. It also contains a domain that has a strong affinity for advanced glycation endproducts (AGEs) [13], and has been used for the removal of AGEs in diabetic patients[14]

Lactoferrin is a member of the transferring family of iron - binding proteins, numerous functions have been reported and continue to be reported for the protein, some of which are related to its iron-binding properties . Its extensive antimicrobial activities were originally attributed to its ability to sequester essential iron, however, it is now established that it possesses bactericidal activities as a result of a direct interaction between the protein or lactoferrin -derived peptides [15] .

The aim of this study was to investigate some of medicinal plants on the activity of some immunological factors in saliva and serum of type-II Diabetes mellitus .

\section{Materials and Methods: Samples Collection:}

The samples consisted of 45 males and females of diabetic patients type- II were included in this study aged from 40-69 year. All the patients have no history of any systemic diseases, not smoking, not receiving any medicines or antibiotics at least one month duration before investigation and they were diabetic patients type-II . All the samples were taken from patients that were regularly visit the Diabetic Center Mustansriya University - Baghdad. The control samples consisted of 45 healthy males and females without periodontal diseases and having the same information that were collected from diabetic patients. The diabetic patients were divided into three groups as suggested by [16].

-GroupI : Chronic periodontitis patients with mild severity (1-3 mm Clinical Attachment Loss CAL).

-Group II Chronic periodontitis patients with severe destruction (4-5 mm CAL).

-Group III: Bleeding and swollen gum with pockets that measure up to $6 \mathrm{~mm}$ and more.

\section{Collection of Serum and Saliva Samples Before Treatment:}

The blood were taken from the patients and controls, then 
immediately centrifuged and the serum was separated into many test tubes, each one contain about $1 \mathrm{ml}$ of serum for different treatments and finally stored at $-20{ }^{\circ} \mathrm{C}$ [17]. Saliva samples were taken from the diabetic subjects and periodontally healthy subjects control. Asking them that they were not eat or drink (except water) at least 1 hour before collection of the sample. The patients and controls rinse their mouth several time by water and then wait for 1-2 minutes for water clearance, $10 \mathrm{ml}$ of whole sunstimulate mixed saliva was collected into polyethylene tubes using a standardized method according to [18].The saliva sample was heated to $56{ }^{\circ} \mathrm{C}$ in a water bath for 30 minutes for complement inactivation. No loss of antibody activity could be demonstrated by using this approach [19]. The samples were then centrifuged at $5000 \mathrm{rpm}$ for 30 minutes at $4{ }^{\circ} \mathrm{C}$, this was done within one hour after collection, the clear supernatant was separated by Pasteur pipettes and also divided into several polyethylene tubes, $1 \mathrm{ml}$ of the supernatant saliva in each tube for different treatments and stored at $-20{ }^{\circ} \mathrm{C}$ in deep freeze for less than one month. The blood sample collected from NIDDM and saliva called samples before treatment with mixture of plants.

Collection of Blood \& Saliva after Treatment with medicinal plants:

After giving the diabetic subjects type 2 patients the medicinal plants to treat the inflammation of gingiva by putting $2 \mathrm{~g}$ crude powder of each type and the mixture of these plants on all surface of the gingival, and leave it for 5 minutes, then rinse the mouth with water. Repeat the application of medicinal plants after each lunch and continue using it for 4 days. After that the serum and saliva samples were taken by the same way as mentioned before and pointed as samples after treatment [20]as shown bellow:

* Treatment 1:Using Quercus infector $(30 \%)$, for treatment the gingiva in 45 patients of diabetic patients.

* Treatment II:Using Thuja occidentalis $(20 \%)$, for treatment the gingiva in 45 patients of diabetic patients.

* Treatment III:Using Terminalia chebula (40\%), for treatment the gingiva in 45 patients of diabetic patients.

* Treatment IV:Using Anethum graveolens $(10 \%)$, for treatment the gingiva in 45 patients of diabetic patients.

* Treatment V: Using the mixture of four medicinal plants in the treatment in 45 patients of diabetic patients.

Determination of Immunoglobulin IgA:

The standard curve of $\operatorname{IgA}$ were estimated by single radial immunodiffusion technique as shown in Fig: 1 , using the method of Mancini, et al. [21] low concentration of immunodiffusion plates for quantitative determination of protein in low concentration ranges . The salivary and serum levels of IgA for diabetic patients and control were estimated by the same method and compare the values with the standard curve of $\operatorname{Ig} \mathrm{A}$

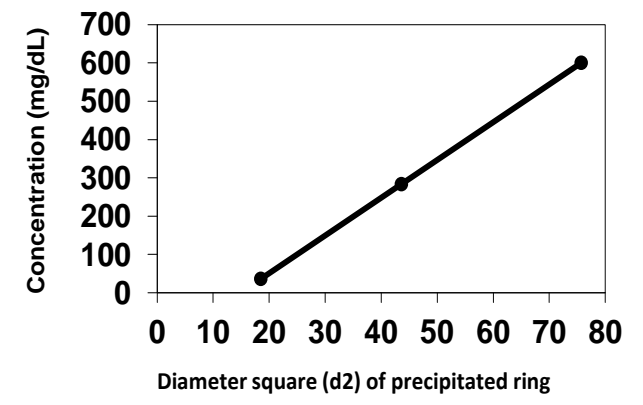

Fig(1): Standard Curve for IgA Estimation Direct "Sandwich" ELISA for measurement of lysozyme in serum and saliva: 
Estimation of lysozyme level in serum and saliva by ELISA method. There was three immunological steps: In the first step, the primary (monoclonal) antibody bound to the wells of a microtiter plate. In the second step, the addition of secondary polyclonal (Goat anti-mouse $\mathrm{IgG}$ ) antibody linked with a biotinylated monoclonal antibody to form purified IgG conjugated to HRPlyophilised [22]. In the third step, if the conjugated secondary antibody is not available using other polyclonal antibody (rabbit-antihuman lysozyme) to form the solid phase antibodyantigen complex , which in turn, binds the conjugate [23]. After incubation the wells were washed and the antigen complex bound to the well detected by addition of a chromogenic substrate. The intensity of the color developed is directly related to the specific monoclonal antibody concentration of the sample [24], Fig:2 show the standard curve of lysozyme determination according to Glodsby et al. [24] method called direct "Sandwich"ELISA for measurement of lysozyme level and compare the values of lysozyme in serum and saliva for diferrent groups of diabetic patients with the standard curve of lysozyme values .

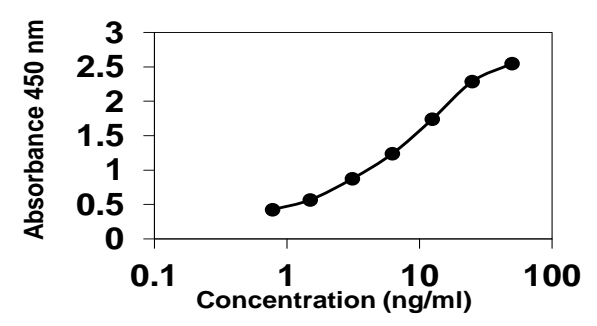

Fig(2) Standard curve for Lysozyme determination Direct"Sandwic ELISA for measurement of lactoferrin in serum and saliva:

The estimation of lactoferrin in serum and saliva by ELISA method. There is two immunological steps. In the first step, the primary ( monoclonal) antibody, sheep: Ig-AS, EIA (kit) $16 \mathrm{mg} / \mathrm{ml}$, bound to the wells of a microtiter plate . In the second step, the addition of secondary polyclonal antibody sheep: Ig-HRP conjugate , IHC/EIA, to form the antibodyantigen complex and in turns, binds the conjugate. After incubation, the wells are washed and the antigen complex bound to the well detected by addition of a chromogenic substrate. The intensity of the color developed is directly related to the specific concentration of the sample [24].

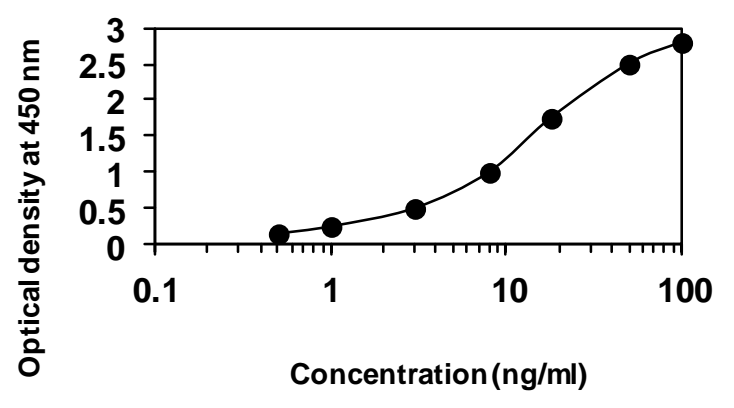

\section{Fig( 3 ): $\quad$ Standard curve for the determination of lactoferrin}

Fig: 3 , show the standard curve of lactoferrin determination according to Glodsby et al. [24] method called direct "Sandwich"ELISA for measurement of lactoferrin level,and compare the values of lactoferrin in serum and saliva for diferrent groups of diabetic patients with the standard curve of lactoferrin values.

Statistical Analysis:The data were processed and analyzed using the statistic package for social sciences (SPSS Inc. 2000, versio 10.1) for windows and excel 2000 . Both descriptive and inferential statistics were used.

A $\mathrm{P}$ value of $\mathrm{P} \leq 0.05^{*}$ was accepted as statistically significant, and also the 
$\mathrm{P}$ value $\leq 0.01 * *$ and the $\mathrm{P}$ value of $\leq 0.001 * * *$.

Descriptive statistics:

* Mean

* Percentage

* Standard Deviation (SD)

* Statistical tables

Inferential statistics:

* Paired samples T-test.

* Unpaired samples T-test.

* Pearson's coefficient of correlation

\section{Result and Discussion:}

1-Serum and Saliva of

Immunoglobulin A:
The results in table 1,2 , the mean serum $\operatorname{IgA}$ values were $185.0 \pm 52.9(\mathrm{mg} / \mathrm{dl})$, whereas the mean salivary IgA values were $268.3 \pm$ $78.0(\mathrm{mg} / \mathrm{dl})$ for healthy individuals. The high concentration of immunoglobulin IgA in saliva may be concluded due to the presence of oral lesions that permits the passage of globulin rich exudates into the saliva. Therefore the lesions or periodontitis can be considered as an additional source of immunoglobulins in saliva.

Table 1- Effect of different treatments on serum $\operatorname{IgA}$ in diabetic patients.

\begin{tabular}{|c|c|c|c|c|c|c|}
\hline & \multicolumn{6}{|c|}{ Serum IgA Mean \pm SD $(\mathrm{mg} / \mathrm{dl})$} \\
\hline Groups & $\begin{array}{l}\text { Before } \\
\text { Treat. }\end{array}$ & $\begin{array}{l}\text { Quercus } \\
\text { robur } \\
\text { (T1) }\end{array}$ & $\begin{array}{l}\text { Thuja } \\
\text { occidentalis } \\
\text { (T2) }\end{array}$ & $\begin{array}{l}\text { Terminalia } \\
\text { chebula } \\
\text { (T3) }\end{array}$ & $\begin{array}{l}\text { Anethum } \\
\text { graveolens } \\
\text { (T4) }\end{array}$ & $\begin{array}{l}\text { Mixture } \\
\text { of four } \\
\text { plants } \\
\text { (T5) }\end{array}$ \\
\hline Control & $\begin{array}{l}185.0 \\
\pm 52.9\end{array}$ & $\begin{array}{l}185.0 \pm \\
52.9\end{array}$ & $\begin{array}{l}185.0 \\
52.9\end{array}$ & $\begin{array}{l}185.0 \\
52.9\end{array}$ & $\begin{array}{l}185.0 \\
52.9\end{array}$ & $\begin{array}{l}185.0 \pm \\
52.9\end{array}$ \\
\hline $\begin{array}{l}\text { Group } \\
\text { I }\end{array}$ & $\begin{array}{l}338.6 \\
\pm \\
160.5 \\
\S \S \S\end{array}$ & $\begin{array}{l}453.9 \pm \\
180.3 \\
\S \S \S\end{array}$ & $\begin{array}{l}475.9 \\
153.0 \\
\S \S \S\end{array}$ & $\begin{array}{l}513.9 \\
70.5 \\
\S \S \S\end{array}$ & $\begin{array}{l}482.8 \\
107.1 \\
\S \S \S\end{array}$ & $\begin{array}{l}516.1 \quad \pm \\
93.2 \\
\S \S \S\end{array}$ \\
\hline $\begin{array}{l}\text { Group } \\
\text { II }\end{array}$ & $\begin{array}{l}506.7 \\
\pm \\
104.4 \\
\S \S \S\end{array}$ & $\begin{array}{l}473.2 \pm \\
67.3 \\
\S \S \S\end{array}$ & $\begin{array}{l}512.5 \\
58.7^{*} \\
\S \S \S\end{array}$ & $\begin{array}{l}500.3 \\
46.0 \\
\S \S \S\end{array}$ & $\begin{array}{l}484.5 \\
49.4 \\
\S \S \S\end{array}$ & $\begin{array}{l}532.5 \quad \pm \\
79.7 \\
\S \S \S\end{array}$ \\
\hline $\begin{array}{l}\text { Group } \\
\text { III }\end{array}$ & $\begin{array}{l}452.7 \\
\pm 62.1 \\
\S \S \S \\
\end{array}$ & $\begin{array}{ll}441.0 \quad \pm \\
66.4 & \\
\S \S \S & \end{array}$ & $\begin{array}{l}432.0 \\
83.0 \\
\S \S \S \\
\end{array}$ & $\begin{array}{l}537.5 \\
55.9 \\
\S \S \S \\
\end{array}$ & $\begin{array}{l}492.7 \\
85.7 \\
\S \S \S \\
\end{array}$ & $\begin{array}{ll}508.1 \quad \pm \\
62.9 \\
\S \S \S\end{array}$ \\
\hline
\end{tabular}

* Significant difference from pervious treatment at $\mathrm{p} \leq 0.05$, ** at $\mathrm{p} \leq 0.01$ and $* * *$ at $\mathrm{p} \leq 0.001$

$\S$ Significant difference from control at $\mathrm{p} \leq 0.05, \S \S$ at $\mathrm{p} \leq 0.01$ and $\S \S \S$ at $\mathrm{p} \leq 0.001$

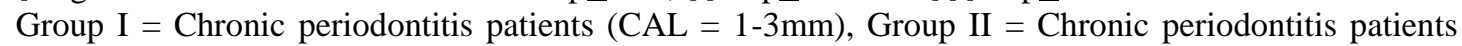
$(\mathrm{CAL}=4-5 \mathrm{~mm})$ and Group $\mathrm{III}=$ patients with $\mathrm{CAL}=6 \mathrm{~mm}$ and more. $\mathrm{T} 1,2,3,4,5=$ Treatments 1,2 , $3,4,5$

Also in table 1, 2 there was a significant increase at $(\mathrm{P}<0.001)$ in the mean serum and salivary $\operatorname{IgA}$ between different groups of diabetic patients (before and after treatment) and with the control. This finding is in agreement with the previous study by [25], that showed the severity of periodontitis could be positively corleated with increased IgA concentrations, and there was a significant association between the diabetes mellitus and severe periodontal disease [26], and also the inaccuracy of estimating salivary $\operatorname{IgA}$ concentration is enhanced by loss of immunoglobulins during the process of concentration and by the adhesiveness of

$\operatorname{IgA}$ to surface, and this will be in contrast with that found by [27], who showed that the fluid in gingival sulcus contained the same amount of $\mathrm{IgG}$, IgA and $\operatorname{IgM}$ globulins as was found in their sera, but $\operatorname{IgG}$ and $\operatorname{IgA}$ were greatly decreased and IgM was absent in whole saliva 
Table 2- Effect of different treatments on $\operatorname{IgA}$ in saliva of different groups of diabetic patients .

\begin{tabular}{|c|c|c|c|c|c|c|}
\hline & \multicolumn{6}{|c|}{ Salivary IgA Mean \pm SD (mg/dl) } \\
\hline Groups & $\begin{array}{l}\text { Before } \\
\text { Treat. }\end{array}$ & $\begin{array}{l}\text { Quercus } \\
\text { Robur } \\
\text { (T1) }\end{array}$ & $\begin{array}{l}\text { Thuja } \\
\text { occidentalis } \\
\text { (T2) }\end{array}$ & $\begin{array}{l}\text { Terminalia } \\
\text { chebula } \\
\text { (T3) }\end{array}$ & $\begin{array}{l}\text { Anethum } \\
\text { graveolens } \\
\text { (T4) }\end{array}$ & $\begin{array}{l}\text { Mixture } \\
\text { of four } \\
\text { plants } \\
\text { (T5) }\end{array}$ \\
\hline Control & $\begin{array}{l}268.3 \\
\pm 78.0\end{array}$ & $\begin{array}{l}268.3 \\
\pm 78.0\end{array}$ & $\begin{array}{l}268.3 \\
\pm 78.0\end{array}$ & $\begin{array}{ll}268.3 \quad \pm \\
78.0\end{array}$ & $\begin{array}{l}268.3 \\
\pm 78.0\end{array}$ & $\begin{array}{ll}268.3 \quad \pm \\
78.0\end{array}$ \\
\hline Group I & $\begin{array}{l}343.3 \\
\pm 88.9 \\
\S \S \\
\end{array}$ & $\begin{array}{l}384.6 \pm \\
63.1 \\
\$ \$ \S\end{array}$ & $\begin{array}{l}236.9 \\
\pm 70.4\end{array}$ & $\begin{array}{ll}244.7 \quad \pm \\
88.7 & \end{array}$ & $\begin{array}{l}148.7 \\
\pm 156.2 * \\
\$ \S \S\end{array}$ & $\begin{array}{l}490.7 \pm \\
88.2^{* * * *} \\
\S \S \S\end{array}$ \\
\hline GroupII & $\begin{array}{l}267.7 \\
\pm 42.1\end{array}$ & $\begin{array}{l}371.3 \\
\pm 101.7 * * \\
\S \S \S \\
\end{array}$ & $\begin{array}{l}193.6 \\
\pm 61.6^{* * * *} \\
\S \S \S \\
\end{array}$ & $\begin{array}{l}274.7 \\
\pm 42.5 * *\end{array}$ & $\begin{array}{l}81.9 \\
\pm 25.3 * * * \\
\S \S \S \\
\end{array}$ & $\begin{array}{l}482.7 \\
\pm 103.2 * * * \\
\S \S \S \\
\end{array}$ \\
\hline $\begin{array}{l}\text { Group } \\
\text { III }\end{array}$ & $\begin{array}{l}293.5 \\
\pm 48.5\end{array}$ & $\begin{array}{l}374.7 \\
\pm 42.3 * * * \\
\S \S \S\end{array}$ & $\begin{array}{l}217.3 \\
\pm 56.3 * * * \\
\S\end{array}$ & $\begin{array}{ll}258.9 & \pm \\
74.6^{*} & \end{array}$ & $\begin{array}{l}97.7 \quad \pm \\
31.2^{* * * *} \\
\$ \S \S\end{array}$ & $\begin{array}{l}477.4 \quad \pm \\
87.4 * * * \\
\S \S \S\end{array}$ \\
\hline
\end{tabular}

* Significant difference from pervious treatment at $\mathrm{p} \leq 0.05$, ** at $\mathrm{p} \leq 0.01$ and $* * *$ at $\mathrm{p} \leq 0.001$ $\S$ Significant difference from control at $\mathrm{p} \leq 0.05, \S \S$ at $\mathrm{p} \leq 0.01$ and $\S \S \S$ at $\mathrm{p} \leq 0.001$

Group I $=$ Chronic periodontitis patients $(\mathrm{CAL}=1-3 \mathrm{~mm})$, Group II $=$ Chronic periodontitis patients $(\mathrm{CAL}=4-5 \mathrm{~mm})$ and Group III $=$ patients with $\mathrm{CAL}=6 \mathrm{~mm}$ and more. $\mathrm{T} 1,2,3,4,5=$ Treatments 1,2 , $3,4,5$

The locally produced IgA (Gingival immunocytes) or serum derived $\operatorname{Ig} \mathrm{A}$ that increased by increase leakage from periodontal pockets contributes to the elevated IgA levels of whole saliva from individuals with periodontal disease, also increased glandular secretion from major salivary glands [28]. The increased level of IgA concentration in diabetic patient of different degree of periodontitis, the possible explanation may be that the majority of $\operatorname{IgA}$ are susceptible to cleavage and inactivation by members of the subgingival microflora associated with periodontal disease. Thus, several members of the subgingival microflora i.e. Bacteriodes, cabnocytophaga and veillonella species, excrete proteases capable of including specific cleavage of $\operatorname{IgA}$ in the hing region, resulting in the release on intact monomeric and unfunctional $\mathrm{Fab}$ and $\mathrm{Fc}$ fragments[29].

2- Serum and Salivary lysozyme:
The results in table -3 showed that the lysozyme concentration in serum of different groups of diabetic patients(before treatment) were not significant when compared with the control, whereas the lysozyme concentration in different groups of diabetic patients (after treatment) showed highly significant at $(\mathrm{P}<0.001)$ when compared with the control, and the best results of lysozyme concentration by the application of mixture of these plants (T5). Also the results in table - 4 showed that there was an elevation of whole unstimulated saliva lysozyme levels in NIDDM patients when compared with the controls. This suggests that the inflamed gingival mucosa be one of lysozyme source in the oral cavity. Diabetes is associated with an increased risk of developing inflammatory diseases [30], in an attempt to clarify the mechanism of increased susceptibility to oral infection in diabetics, we detect the levels of salivary antimicrobial factors, including lysozyme 
Table 3- Effect of different treatments on lysozyme concentration in serum of different groups of diabetic patients.

\begin{tabular}{|c|c|c|c|c|c|c|}
\hline \multirow[b]{2}{*}{ Groups } & \multicolumn{6}{|c|}{ Serum lysozyme Mean \pm SD $(\mathrm{mg} / \mathrm{dl})$} \\
\hline & $\begin{array}{l}\text { Before } \\
\text { Treat. }\end{array}$ & $\begin{array}{l}\text { Quercus } \\
\text { Robur } \\
\text { (T1) }\end{array}$ & $\begin{array}{l}\text { Thuja } \\
\text { occidentalis } \\
\text { (T2) }\end{array}$ & $\begin{array}{l}\text { Torminalia } \\
\text { Chebula } \\
\text { (T3) }\end{array}$ & $\begin{array}{l}\text { Anethum } \\
\text { graveolens } \\
\text { (T4) }\end{array}$ & $\begin{array}{l}\text { Mixture of } \\
\text { four plants } \\
\text { (T5) }\end{array}$ \\
\hline Control & $3.4 \pm 0.3$ & $3.4 \pm 0.3$ & $3.4 \pm 0.3$ & $3.4 \pm 0.3$ & $3.4 \pm 0.3$ & $3.4 \pm 0.3$ \\
\hline Group I & $3.4 \pm 0.7$ & $\begin{array}{ll}4.4 & \pm \\
0.7^{* *} & \\
\S \S \S & \\
\end{array}$ & $\begin{array}{l}4.8 \pm 0.5 \\
\S \S \S\end{array}$ & $\begin{array}{l}4.7 \pm 0.7 \\
\S \S \S\end{array}$ & $\begin{array}{l}5.4 \pm 0.7 * \\
\S \S \S\end{array}$ & $\begin{array}{l}7.6 \pm 0.7 * * * \\
\S \S \S\end{array}$ \\
\hline $\begin{array}{l}\text { Group } \\
\text { II }\end{array}$ & $3.5 \pm 0.8$ & $\begin{array}{l}4.3 \pm * * * \\
\S \S \S\end{array}$ & $\begin{array}{l}4.1 \pm 0.6 \\
\S \S \S\end{array}$ & $\begin{array}{l}4.5 \pm 0.4^{*} \\
\S \S \S \\
\end{array}$ & $\begin{array}{l}5.1 \pm 0.7^{* * *} \\
\S \S \S\end{array}$ & $\begin{array}{l}7.7 \pm 0.6^{* * * *} \\
\S \S \S\end{array}$ \\
\hline $\begin{array}{l}\text { Group } \\
\text { III }\end{array}$ & $3.1 \pm 0.6$ & $\begin{array}{ll}4.2 & \pm \\
0.2 * * * & \\
\S \S \S & \\
\end{array}$ & $\begin{array}{l}4.2 \pm 0.5 \\
\S \S \S\end{array}$ & $\begin{array}{l}4.7 \pm 0.5^{*} \\
\S \S \S\end{array}$ & $\begin{array}{l}5.1 \pm 0.7 * \\
\S \S \S\end{array}$ & $\begin{array}{l}7.7 \pm 0.5^{* * * *} \\
\S \S \S\end{array}$ \\
\hline
\end{tabular}

* Significant difference from pervious treatment at $\mathrm{p} \leq 0.05$, ** at $\mathrm{p} \leq 0.01$ and $* * *$ at $\mathrm{p} \leq 0.001$

$\S$ Significant difference from control at $\mathrm{p} \leq 0.05, \S \S$ at $\mathrm{p} \leq 0.01$ and $\S \S \S$ at $\mathrm{p} \leq 0.001$ Group $\mathrm{I}=$ Chronic periodontitis patients $(\mathrm{CAL}=1-3 \mathrm{~mm})$, Group $\mathrm{II}=$ Chronic periodontitis patients $(\mathrm{CAL}=4-5 \mathrm{~mm})$ and Group III = patients with $\mathrm{CAL}=6 \mathrm{~mm}$ and more. $\mathrm{T}$ 1, 2, 3, 4,5 = Treatments $1,2,3,4,5$

Table 4- Effect of different treatments on lysozyme concentration in saliva of different groups of diabetic patients.

\begin{tabular}{|c|c|c|c|c|c|c|}
\hline \multirow[b]{2}{*}{ Groups } & \multicolumn{6}{|c|}{ Salivary lysozyme Mean $\pm \mathrm{SD}(\mathrm{mg} / \mathrm{ml})$} \\
\hline & $\begin{array}{l}\text { Before } \\
\text { Treat. }\end{array}$ & $\begin{array}{l}\text { Quercus } \\
\text { robur } \\
\text { (T1) }\end{array}$ & $\begin{array}{l}\text { Thuja } \\
\text { occidentalis } \\
\text { (T2) }\end{array}$ & $\begin{array}{l}\text { Terminalia } \\
\text { chebula } \\
\text { (T3) }\end{array}$ & $\begin{array}{l}\text { Anethum } \\
\text { graveolens } \\
\text { (T4) }\end{array}$ & $\begin{array}{l}\text { Mixture of } \\
\text { four } \\
\text { plants } \\
\text { (T5) }\end{array}$ \\
\hline Control & $5.7 \pm 1.6$ & $5.7 \pm 1.6$ & $5.7 \pm 1.6$ & $5.7 \pm 1.6$ & $5.7 \pm 1.6$ & $5.7 \pm 1.6$ \\
\hline Group I & $\begin{array}{l}8.1 \pm 0.8 \\
\S \S \S\end{array}$ & $\begin{array}{l}9.5 \pm 0.9 * * * \\
\S \S \S\end{array}$ & $\begin{array}{l}9.6 \pm 0.3 \\
\S \S \S\end{array}$ & $\begin{array}{l}10.0 \pm 0.7 * \\
\S \S \S\end{array}$ & $\begin{array}{l}10.0 \pm 0.8 \\
\S \S \S\end{array}$ & $\begin{array}{l}10.3 \pm 1.1 \\
\S \S \S\end{array}$ \\
\hline $\begin{array}{l}\text { Group } \\
\text { II }\end{array}$ & $\begin{array}{l}7.9 \pm 0.6 \\
\S \S \S\end{array}$ & $\begin{array}{l}9.8 \pm 1.0 * * * \\
\S \S \S\end{array}$ & $\begin{array}{l}9.4 \pm 0.4 \\
\S \S \S\end{array}$ & $\begin{array}{l}9.7 \pm 0.8 \\
\S \S \S\end{array}$ & $\begin{array}{l}9.7 \pm 0.3 \\
\S \S \S\end{array}$ & $\begin{array}{l}10.2 \pm 1.1 \\
\S \S \S\end{array}$ \\
\hline $\begin{array}{l}\text { Group } \\
\text { III }\end{array}$ & $\begin{array}{l}8.0 \pm 0.8 \\
\S \S \S\end{array}$ & $\begin{array}{l}9.9 \pm 0.7 * * * \\
\S \S \S\end{array}$ & $\begin{array}{l}9.5 \pm 0.5 \\
\S \S \S\end{array}$ & $\begin{array}{l}9.9 \pm 1.5 \\
\S \S \S\end{array}$ & $\begin{array}{l}8.1 \pm 0.8 \\
\S \S \S\end{array}$ & $\begin{array}{l}9.5 \pm 0.9 * * \\
\S \S \S\end{array}$ \\
\hline
\end{tabular}

$*$ Significant difference from pervious treatment at $\mathrm{p} \leq 0.05, * *$ at $\mathrm{p} \leq 0.01$ and $* * *$ at $\mathrm{p} \leq 0.001$

$\S$ Significant difference from control at $\mathrm{p} \leq 0.05, \S \S$ at $\mathrm{p} \leq 0.01$ and $\S \S \S$ at $\mathrm{p} \leq 0.001$ Group $\mathrm{I}=$ Chronic periodontitis patients $(\mathrm{CAL}=$

$1-3 \mathrm{~mm})$, Group II = Chronic periodontitis patients $(\mathrm{CAL}=4-5 \mathrm{~mm})$ and Group III = patients with $\mathrm{CAL}=6 \mathrm{~mm}$ and more. $\quad \mathrm{T} 1,2,3,4,5=$ Treatments $1,2,3,4,5$

From these results we can concluded that there was a relationship between salivary composition and oral health and disease and this can be investigated for dental caries and disease of the oral mucosa [31].

3 - Serum and Salivary Lactoferrin (Lf) :

From these observations, we can be concluded that the concentration of Lf was increased among those NIDDM patient groups as compared with the control (healthy) group ,

our knowledge, from other studies that there are a relationship between salivary Lf levels and gingival inflammation. 
Table 5- Effect of different treatments on serum lactoferrin in diabetic patients

\begin{tabular}{|c|c|c|c|c|c|c|}
\hline \multirow[b]{2}{*}{ Groups } & \multicolumn{6}{|c|}{ Serum $(\mathrm{Lf})$ Mean \pm SD $(\mathrm{mg} / \mathrm{ml})$} \\
\hline & $\begin{array}{l}\text { Before } \\
\text { Treat. }\end{array}$ & $\begin{array}{l}\text { Quercus robur } \\
\text { (T1) }\end{array}$ & $\begin{array}{l}\text { Thuja } \\
\text { occidentalis } \\
\text { (T2) }\end{array}$ & $\begin{array}{l}\text { Torminalia } \\
\text { chebula } \\
\text { (T3) }\end{array}$ & $\begin{array}{l}\text { Anethumgra } \\
\text { veolens } \\
\text { (T4) } \\
\end{array}$ & $\begin{array}{l}\text { Mixture of four } \\
\text { plants } \\
\text { (T5) }\end{array}$ \\
\hline Control & $11.8 \pm 1.1$ & $11.8 \pm 1.1$ & $11.8 \pm 1.1$ & $11.8 \pm 1.1$ & $11.8 \pm 1.1$ & $11.8 \pm 1.1$ \\
\hline Group I & $\begin{array}{l}13.0 \pm 1.6 \\
\S \S\end{array}$ & $\begin{array}{l}17.0 \pm 0.9 * * * \\
\S \S \S\end{array}$ & $\begin{array}{l}15.5 \pm 0.4 * * * \\
\S \S \S\end{array}$ & $\begin{array}{l}16.4 \pm 0.5 * * * \\
\S \S \S\end{array}$ & $\begin{array}{l}16.9 \pm 0.7^{*} \\
\S \S \S\end{array}$ & $\begin{array}{l}20.5 \pm 2.2 * * * \\
\S \S \S\end{array}$ \\
\hline Group II & $\begin{array}{l}13.2 \pm 0.3 \\
\S \S \S \\
\end{array}$ & $\begin{array}{l}13.2 \pm 0.6 \\
\S \S \S \\
\end{array}$ & $\begin{array}{l}13.5 \pm 0.5 \\
\S \S \S \\
\end{array}$ & $\begin{array}{l}13.6 \pm 0.4 \\
\S \S \S \\
\end{array}$ & $\begin{array}{l}13.7 \pm 0.6 \\
\S \S \S \\
\end{array}$ & $\begin{array}{l}16.3 \pm 0.4^{* * * *} \\
\S \S \S\end{array}$ \\
\hline Group III & $12.4 \pm 0.6$ & $\begin{array}{l}13.2 \pm 0.5^{* *} \\
\S \S \S\end{array}$ & $\begin{array}{l}13.6 \pm 0.3 \\
\S \S \S\end{array}$ & $\begin{array}{l}13.5 \pm 0.1 \\
\S \S \S\end{array}$ & $\begin{array}{l}13.6 \pm 0.2 \\
\S \S \S\end{array}$ & $\begin{array}{l}15.2 \pm 0.3 * * * \\
\S \S \S\end{array}$ \\
\hline
\end{tabular}

* Significant difference from pervious treatment at $\mathrm{p} \leq 0.05$, ** at $\mathrm{p} \leq 0.01$ and $* * *$ at $\mathrm{p} \leq 0.001 \S$ Significant difference from control at $\mathrm{p} \leq 0.05$, $\S \S$ at $\mathrm{p} \leq 0.01$ and $\S \S \S$ at $\mathrm{p} \leq 0.001$ Group $\mathrm{I}=$ Chronic periodontitis patients $(\mathrm{CAL}=1-3 \mathrm{~mm})$, Group $\mathrm{II}=$ Chronic periodontitis patients $(\mathrm{CAL}=4-5 \mathrm{~mm})$ and Group III = patients with $\mathrm{CAL}=6 \mathrm{~mm}$ and more. $\mathrm{T} 1,2,3,4,5=$ Treatments $1,2,3,4,5$

Table 6- Effect of different treatments on salivary lactoferrin in diabetic patients

\begin{tabular}{|c|c|c|c|c|c|c|}
\hline \multirow[b]{2}{*}{ Groups } & \multicolumn{6}{|c|}{ Salivary (Lf) Mean \pm SD (mg/ml) } \\
\hline & $\begin{array}{l}\text { Before } \\
\text { Treat. }\end{array}$ & $\begin{array}{l}\text { Quercus Robur } \\
\text { (T1) }\end{array}$ & $\begin{array}{l}\text { Thuja } \\
\text { occidentalis } \\
\text { (T2) }\end{array}$ & $\begin{array}{l}\text { Torminalia } \\
\text { chebula } \\
\text { (T3) }\end{array}$ & $\begin{array}{l}\text { Anethumgrave } \\
\text { olens } \\
\text { (T4) }\end{array}$ & $\begin{array}{l}\text { Mixture of } \\
\text { plants } \\
\text { (T5) }\end{array}$ \\
\hline Control & $11.3 \pm 0.8$ & $11.3 \pm 0.8$ & $11.3 \pm 0.8$ & $11.3 \pm 0.8$ & $11.3 \pm 0.8$ & $11.3 \pm 0.8$ \\
\hline Group I & $\begin{array}{l}11.8 \pm 0.2 \\
\S\end{array}$ & $\begin{array}{l}12.7 \pm 0.4 * * * \\
\S \S \S\end{array}$ & $\begin{array}{l}13.3 \pm 0.3 * * \\
\S \S \S\end{array}$ & $\begin{array}{l}13.3 \pm 0.3 \\
\S \S \S\end{array}$ & $\begin{array}{l}14.3 \pm 0.8 * * * \\
\S \S \S\end{array}$ & $\begin{array}{l}15.4 \pm 0.2^{* * * *} \\
\S \S \S\end{array}$ \\
\hline Group II & $\begin{array}{l}12.0 \pm 0.3 \\
\S \S\end{array}$ & $\begin{array}{l}12.5 \pm 0.3^{* * * *} \\
\S \S \S\end{array}$ & $\begin{array}{l}12.6 \pm 0.3 \\
\S \S \S\end{array}$ & $\begin{array}{l}12.6 \pm 0.3 \\
\S \S \S\end{array}$ & $\begin{array}{l}12.6 \pm 0.3 \\
\S \S \S\end{array}$ & $\begin{array}{l}12.7 \pm 0.4 \\
\S \S \S\end{array}$ \\
\hline Group III & $\begin{array}{l}12.5 \pm 0.1 \\
\S \S \S\end{array}$ & $\begin{array}{l}12.7 \pm 0.1 * * * \\
\S \S \S\end{array}$ & $\begin{array}{l}12.0 \pm 0.3 * * * \\
\S \S \S\end{array}$ & $\begin{array}{l}12.1 \pm 0.2 \\
\S \S \S\end{array}$ & $\begin{array}{l}12.2 \pm 0.2 \\
\S \S \S\end{array}$ & $\begin{array}{l}12.4 \pm 0.1 \text { *** } \\
\S \S \S\end{array}$ \\
\hline
\end{tabular}

* Significant difference from pervious treatment at $\mathrm{p} \leq 0.05, * *$ at $\mathrm{p} \leq 0.01$ and $* * *$ at $\mathrm{p} \leq 0.001 \S$ Significant difference from control at $\mathrm{p} \leq 0.05$, $\S \S$ at $\mathrm{p} \leq 0.01$ and $\S \S \S$ at $\mathrm{p} \leq 0.001$ Group $\mathrm{I}=$ Chronic periodontitis patients $(\mathrm{CAL}=1-3 \mathrm{~mm})$, Group $\mathrm{II}=$ Chronic periodontitis patients $(\mathrm{CAL}=4-5 \mathrm{~mm})$ and Group III = patients with $\mathrm{CAL}=6 \mathrm{~mm}$ and more. $\mathrm{T}$ 1, 2, 3, 4,5 = Treatments 1, 2, 3, 4,5

The first function attributed to Lf, an iron binding protein belonging to the non - immune natural defenses, it was antimicrobial activities, required direct interaction between this cationic protein and microbial surface components [32]. Lactoferrin inhibits bacterial adhesion on abiotic surfaces through ionic to biomaterials, or specific binding to bacterial structures or both. Lactoferrin activity was strongly influenced by environmental $\mathrm{pH}$. Progressive loss of Lf activity with increasing $\mathrm{pH}$ may reflect increased protonation of anionic targets or physical alteration in the bacterial surface which may hinder Lf binding . Lactoferrin function as immunomodulatory by affecting cell-mediated host responses, and has a high affinity for surface receptors found on activated lymphocytes . Lf also activate natural killer cells, activate PMN cells, regulate lymphokine - activated killer cells , and potentiate macrophage toxicity [33] .

\section{References:}

1- Kim H.S.,( 2005) ; "Do not put too much value on conventional medicines," Journal of Ethnopharmacology, 100, (1-2):37-39.

2-Cowan, M.M., (1999). "Plant products as antimicrobial agents Clinical," Microbiology Reviews, 12 (4): 564-582.

3-Romero, C,D., Choph,S.E., Buck,G., Martinez,E., Garcia,M. and Bixby,L.( 2005); Antibacterialproperties of common herbal remedies of the southwest.Ethnopharmacol. 99:253257. 
4-Alali F. and T. Al-Lafi, ,( 2003); "GC-MS analysis and bioactivity testing of the volatile oil from the leaves of the toothbrush tree Salvadora persica L," Natural Product Research, 17(3):189-194.

5- Deane, P.M., (2005) ; Conifer pollen sensitivity in Westren New York: Cedar pollens . Allergy Asthma Proc., 26 (5): 352-5.

6-Mha and Kunicka,A. , (2003);"Antibacterial and antifungal properties of essential oils," Current Medicinal Chemistry, Vol. 10, No. 10, pp. 813-829.

7- Dutta, B.K. and Rahman, I., (1998); Antifungal activity of Indian plant extracts. Mycoses, 41 (11-12): 535536.

8-Pascal, J.D.; Stanick, K.; Girard, B. and Mazza, G., (2002); Antimicrobial activity of individual and mixed fractions of dill, cilantro, coriander and eucalyptus essential oils. Inter $\mathbf{J}$ of food Microbiol., 74: 101-109.

9-International Expert Committee (2009). International Expert Committee report on the role of the A1C assay in the diagnosis of diabetes. Diabetes Care ;32:1327-1334.

10-Iacopino AM.(2001) Periodontitis and diabetes interrelationships: role of inflammation. Ann. Periodontol ;6(1):125-37 .

11-Jorgensen GH, Arnlaugsson S, Theodors A, Ludviksson BR. ( 2010); Immunoglobulin A deficiency and oral health status: a case-control study. J Clin Periodontol.;37(1):1-8.

12-Renata C-R,Grzegorz L.,Jacek k.,(2009); Antibacterial activity of hen egg white lysozyme modified by thermochemical technique.Euro.Food Res.and Tech.228(5):841-845.

13-Karima M, Kantarci A, Ohira T, Hasturk H, Jones VL, Nam BH, et al. (2005); Enhanced superoxide release and elevated protein kinase $\mathrm{C}$ activity in neutrophils from diabetic patients: association with periodontitis. $\mathbf{J}$ Leukoc Biol. 78(4):862-70.

14-Zheng F, Cai W, Mitsuhashi T, Vlassara H. (2001); Lysozyme enhances renal excretion of advanced glycation endproducts in vivo and suppresses adverse age-mediated cellular effects in vitro: a potential AGE sequestration therapy for diabetic nephropathy? Mol Med. 7(11):737-47. 15-Garcia-Montoya I.A., Cendon T.S., Arevalo-Gallegos S.,Rascon-Cruz Q.(2012);

Lactoferrin multiple bioactive protein: an overview. Bioch.Biophys. Acta 1820(3): 226-36.

16-Annals, (1999). International workshop for a classification of periodontal diseases and conditions Periodontology., 4: 32-53.

17-Shillitoe, E. J. and Lehner, T., (1972). Immunoglobulins and complement: in crevicular fluid,serum and saliva in man. Archive of Oral Biology., 17: 241-245.

18-Thylstrup $\mathrm{A}$ and Fejerskov O (1996). Textbook of clinical cariology $2^{\text {nd }}$ edition, Munksgaard, $17-43$.

19- Everhart, D.L.; Klapper, B.; Carter, W.H. and Moss, S., (1977). Evaluation of dental caries experience and salivary IgA in children ages 3-7. Caries Res., 11: 211-215.

20-Rawdha K.M.,(2008) Effect of some medicinal plants on inflamed periodontium in type 2 diabetics, pp48.

21-Mancini, G.; Carbonara, A.Q. and Heremans, J.F., (1965). Immunochemical quantitation of antigens by single radical immunodiffusion. Immunochemistry, 2: 235 .

22-Farr, A.E. and Nakane, P.K., (1981). Immuno histochemistry with enzyme labeled antibodies: a brief review. J Immunol Methods. 47:129144.

23-Utermohlen, O.,(2003). J Immunol., 170: 2621-2628. 
24-Glodsby, R.A.; Kindt, T.J. and Osborne, B.A., (2000) Generation of B-Cell in "Ku by Immunology" Fourth edition. Printed in USA; PartII: Chapter, 6:161-69.

25-Jorgensen GH, Arnlaugsson S, Theodors A, Ludviksson BR. 2010 ;Immunoglobulin A deficiency and oral health status: a case-control study. J Clin Periodontol. Jan 37(1):1-8. 26-Paul, A.M.; Robert, T.W.; Mary, B.M.; Daniel, E.M.; Karen, R.; James, G.; Harvey, M.B.; Heidi, H.; and Trevor, O., (1999). Type 1 diabetes mellitus and oral health: Assessment of Periodontal disease. J Periodontal.,70: 409-417.

27-Brandtzaeg, P.; Fjellander, I. and Gjeruldsen, S., (1970). Human secretory immunoglobulin's I. Salivary secretions from individuals with normal or low levels of serum Immunoglobulin's. Scand J Heamatol Suppl., 12: 3-83.

28-Hotamisligil G.S. (2006); Inflammation and metabolic disorders. Nature. ;444:860-7.
29-Kilian, M., (1981). Degradation of immunoglobulin $A_{1}, A_{2}$ and $G$ by suspected principle Periodontal Pathogens. Infect Immun., 34: 757765.

30-Brian, L. and Thomas, W.O., (2006). Diabetes mellitus and Periodontal diseases. J Periodontal, 77: 1289-1303 .

31-Rautemaa R., A. Lauhio, M. P. Cullinan, and G. J. Seymour(2007). "Oral infections and systemic disease - an emerging problem in medicine," Clini.Microbiol. and Infect., 13(11): 1041- 1047.

32-Valenti, P. and Antonini, G.M., (2006). Lactoferrin: an important host defence against microbial viral attack. J. Cell. \& Mol Life Science (CMLS). 2(22): 2576-2587.

33-Shau, H.; Kim, A. and Golub, H. (1992). Modulation of natural killer and lymphokine - activated killer cell cytotoxicity by lactoferrin $\mathrm{J}$ leukocyte Biol., 51: 343-9.

\section{تأثير بعض النباتات الطبية على فعالية بعض العوامل المناعية في لعاب ومصل مرضى السكر النوع الثاني}

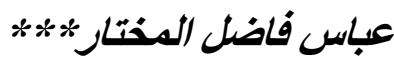

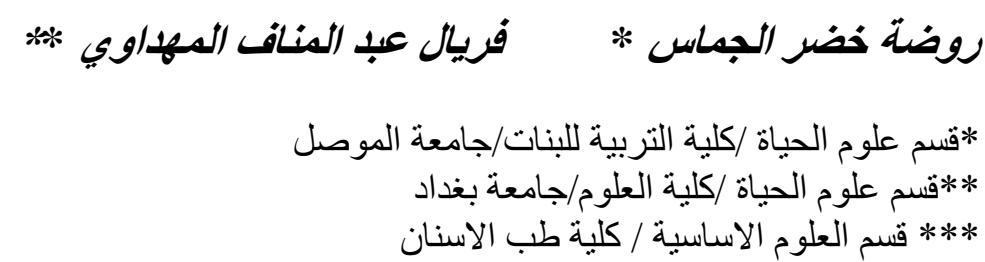

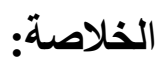

تناولت الدراسة 45 من ذكور و45 من اناث مرضى السكر النوع الثاني و النتي تراوحت اعمار هم بين -

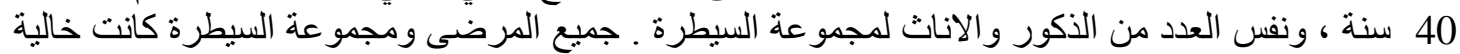

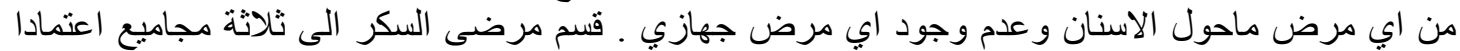

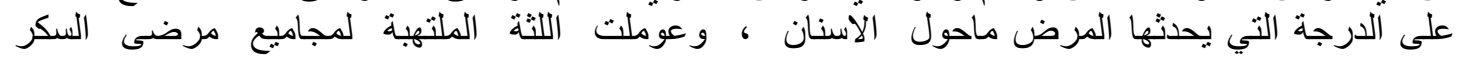

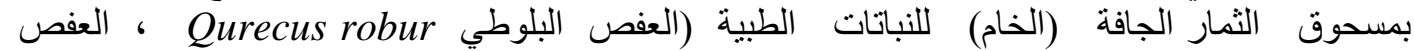

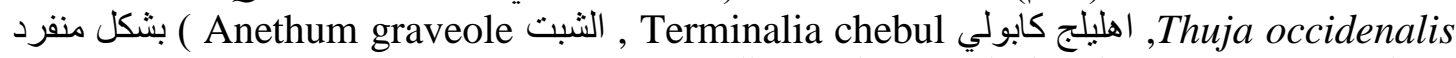

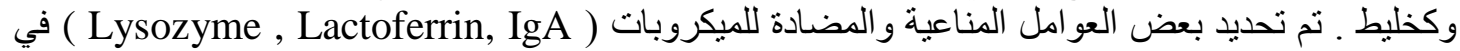

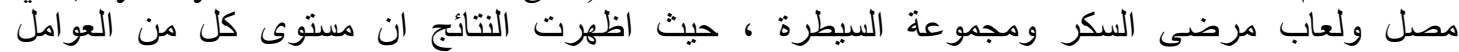
Lysozyme ,IgA

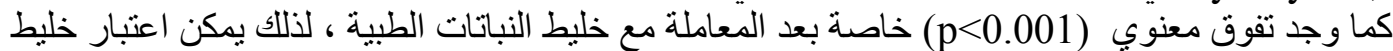
هذه النباتات هو الامثل في معاملة اللثة الملتهبة لمرضى السكر النوع الثناني ـ النيات 